\title{
THE EFFECT OF SUPPLY CHAIN MANAGEMENT PRACTICES AND INFORMATION AND COMMUNICATION TECHNOLOGY ON COMPETITIVE ADVANTAGE AND FIRM PERFORMANCE (CASE STUDY: SMES OF PROCESSED FOOD IN JAKARTA)
}

\author{
Jumady Sinaga *1, Elisa Anggraeni *), and Alim Setiawan Slamet *) \\ *) Department of Management, Faculty of Economics and Management, IPB University \\ Jl. Agatis, Campus of IPB Darmaga Bogor 16680, Indonesia
}

\begin{abstract}
Micro, Small, and Medium Enterprises' (SMEs) development will strengthen domestic economic structure due to the workforce absorption and increase people's purchasing power, the level of demand, and investment growth. Although it has a very strategic role, developing SMEs is not simple. As time goes by, the trend of SMEs selling products online is increasing. Competition is getting tougher, and product innovation is increasingly diverse. Thus, to improve overall performance, SME players must compete to implement strategies. This research aimed to analyze the effect of supply chain management practices on competitive advantage and firm performance, communication, and information technology on supply chain management practices and competitive advantage, and competitive advantage on fir performance. The questionnaires were distributed online to processed food SMEs in Jakarta, using a simple random sampling technique. The samples collected were 244 respondents, and it was analyzed using Structural Equation Modeling (SEM). The results showed that supply chain management practices had a positive effect on competitive advantage. Communication and information technology had a positive effect on supply chain management practices and competitive advantage, and competitive advantage had a positive effect on firm performance.
\end{abstract}

Keywords: competitive advantage, firm performance, ICT, Structural Equation Modeling, supply chain management practices

\begin{abstract}
Abstrak: Berkembangnya UMKM akan memperkuat struktur ekonomi domestik karena terserapnya angkatan kerja, meningkatkan daya beli masyarakat, memperbesar tingkat permintaan dan meningkatkan pertumbuhan investasi. Meski memiliki peran yang sangat strategis, namun untukmengembangkan UMKMbukan hal yang mudah. Seiring perkembangan zaman, tren UMKM dalam penjualan produk melalui online semakin meningkat. Persaingan semakin ketat dan inovasi produk semakin beragam. Sehingga untuk meningkatkan kinerja secara keseluruhan, para pelaku UMKM harus berlomba-lomba untuk melakukan strategi. Tujuan dalam penelitian ini adalah untuk menganalisis pengaruh praktik manajemen rantai pasok terhadap keunggulan bersaing dan kinerja perusahaan, teknologi komunikasi dan informasi terhadap praktik manajemen rantai pasok dan keunggulan bersaing, serta keunggulan bersaing terhadap kinerja perusahaan. Kuesioner dibagikan secara online kepada responden yang merupakan pelaku UMKM pangan olahan di Jakarta, dengan teknik simple random sampling. Jumlah sampel yang dikumpulkan sebanyak 244 responden dan dianalisis dengan menggunakan Structural Equation Modeling (SEM). Hasil penelitian menunjukkan bahwa praktik manajemen rantai pasok berpengaruh positif terhadap keunggulan bersaing, teknologi komunikasi dan informasi berpengaruh positif terhadap praktik manajemen rantai pasok dan keunggulan bersaing, dan keunggulan bersaing berpengaruh positif terhadap dan kinerja perusahaan.
\end{abstract}

Kata kunci: keunggulan bersaing, kinerja perusahaan, praktik supply chain management, Structural Equation Modeling, TIK

\footnotetext{
${ }^{1}$ Corresponding author:

Email: yoo.sinaga@yahoo.com
} 


\section{INTRODUCTION}

Supply chain management in each firm has an important meaning because the supply chain's goals are to meet increasing competition, save costs and maximize profits. A US consultancy first introduced the term supply chain management in the 1980s. Supply chain management is a process of product flow starting from raw materials and then converted into new products to be delivered to consumers. With a supply chain, companies can monitor the flow of information, products, and funds. Supply chains have a complex relationship in maintaining the organization with their business partners to source production and deliver it to consumers (Kalakota and Robinson 2000). In other words, supply chain management aims to connect all parties who have an interest in maximizing productivity and providing benefits (Finch 2006 in Kurniawan et al. 2018).

The practice of supply chain management would like to decrease operating costs that occur along the chain, ensure that product quality is maintained, and ensure product availability and service speed that will provide value to consumers. In the increasingly fierce competition, the firm will continue to provide the best service to customers by considering the costs incurred. The firm will implement an efficient and responsive supply chain strategy. An efficient supply chain is the firm's ability to meet customer demands by reducing costs during the chain process. An efficient supply chain strategy seeks to meet customer demand by minimizing the total cost required (Chopra and Meindl, 2007). Therefore, supply chain management will provide a competitive advantage both directly and indirectly. Meanwhile, a responsive supply chain is defined as a supply chain's ability to anticipate uncertain consumer demand (Holweg, 2005). The higher the supply chain response to customer demand, the customer satisfaction is achieved. High speed and flexibility in the supply chain will increase the supply chain's responsiveness (Prater et al. 2001), but the costs incurred by the firm will also be greater (Chopra and Meindl, 2007).

Due to the current development of industrial revolution technology 4.0, SME's digital marketing is required to be more creative, effective and efficient, and responsive to customer requests. Fajar (2013) stated that information and communication technology's development brings rapid changes in the business world. In the development of this technology, some people call it digital disruption or digital disruption. According to Kasali (2017), disruption is an innovation causing prices to fall, the marketing strategy and corporate strategy change. Digital development is very fast in the business field due to transformation. Taneja and Toombs (2014) argued that media could create visibility, strengthen brand image, and attract new customers. With a digital marketing strategy, it eases consumers to access information on a product, including information on price, brand, quality, form, and others (Wardhana, 2015).

The food and Beverage industry currently become one of the leading sectors of the manufacturing sector in Indonesia. The high value of the food and beverage industry causes this sector to contribute greatly to Indonesia's Gross Domestic Product (GDP). The value of the food and beverage industry showed an increasing trend from 2014 to 2019. In 2014, the food industry's value had reached IDR 125 trillion, and in 2019, it increased to IDR 182 trillion (Kemenperin, 2019).

Based on the Indonesia PwC survey in 2017 in Katadata 2018, as shown in Figure 1, the most sold online marketing products were books, music, movies, and video games, with 59\%. In offline marketing, there was only $41 \%$. Meanwhile, the product that was sold the least through online marketing was foodstuffs of $27 \%$, while in offline marketing, it reached $73 \%$.

The low shopping activity of groceries online is because people avoid high prices, defective products, food forms that do not guarantee taste, and the visual appearance of products that do not guarantee product quality. Another factor is differences in consumer behavior. Schiffman and Kanuk (2008) revealed that consumer behavior is an individual's decision-making to allocate available resources (time, money, effort, and energy) while buying products. Hence, to increase sales with online systems and gain a competitive advantage, companies must use various strategies to improve supply chain management practices and the use of information and communication technology.

In previous research, Abdullah and Musa (2013) said that trust and information-sharing directly affect the relationship commitment. Information sharing is relevant and interesting to be researched and used as an indicator in practical supply chain management. The research of Ibrahim and Hamid (2014) identified influence practical supply chain management that 
covers integration, information sharing, customer management, supply management, and responses to the supply chain's performance. Hence, there was a need to directly measure the impact of the practical approach of supply chain management on firm performance and competitive advantage. Tripathy et al. (2016) said that Information and Communication Technology (ICT) affects logistics, operational, and supply chain effectiveness.

Therefore, other than identifying those three variables, there was a need to identify the direct impact of ICT on SMEs' competitive advantage. Based on mentioned occurrences above, this research aimed to analyze the direct impact of practical supply chain management on the firm performance and its competitive advantage, ICT to the practical supply chain management and competitive advantage, and competitive advantage to the firm performance. So that processed food SMEs in DKI Jakarta can apply practical supply chain management strategy, ICT, competitive advantage, and firm performance to the business' sustainability.

\section{METHODS}

This research focused on processed food SMEs, i.e., processed chips, floss, shrimp paste, tapai, se'i, tempeh chips, cakes, bread, spices, milk, etc. The lifespan range of SMEs included in this research are 1-2.5 years, $>2.5-5$ years, $>$ 5-7.5 years, $>7.5-10$ years, and $>10$ years. Meanwhile, the samples came from owner, directors, or managers.
Data collecting was done from May to June 2020 in DKI Jakarta using questionnaires deployed directly or online. Sample technique used in this research is simple random sampling, all population has the same chance to be chosen as research samples. Meanwhile, the sample size is decided by following Hair et al. (2014), which recommend a sample size of 200. It gave a solid foundation for estimation.

During this research, 927 questionnaires were distributed to respondents, and 249 of them filled the questionnaires with a response rate of $26,86 \%$. There were five questionnaires eliminated because they didn't meet the prerequisites to be analyzed further. Therefore, the total number of questionnaires used are 244 .

The measurement instrument that was used is the Likert scale (Sugiyono 2010), which is: 1) strongly disagree, 2) disagree, 3) undecided, 4) agree, 5) strongly agree. Tools used in this research are Confirmatory Factor Analysis (CFA) and Structural Equation Model (SEM) with Analysis of Moment of Structures (AMOS) approach. According to Ghozali (2008), SEM is a technique of multivariate statistical analysis that enables the researcher to test the impact, directly and indirectly, between complex variables, recursive (repeatedly), and also non-recursive (non-repeated) to get a holistic overview of a model. Figure 2 which shows the conceptual research framework.

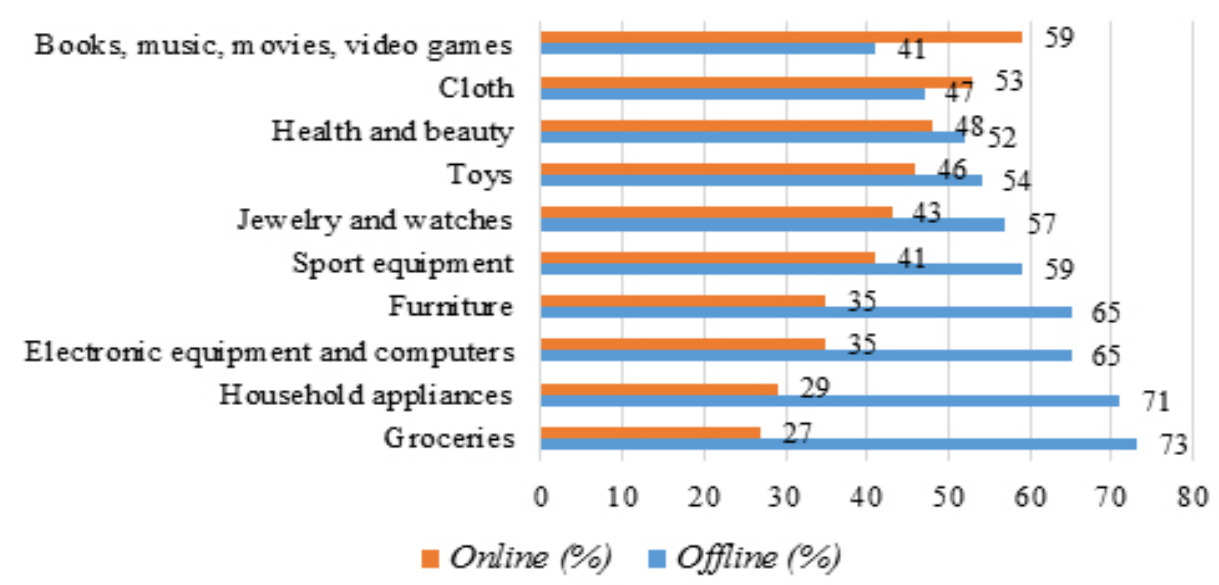

Figure 1. Online and offline shopping preferences (Katadata, 2018) 
Practices of supply chain management have a relationship in creating a firm competitive advantage (Sukati et al. 2011). Supply chain management practices can build competitive advantage in the ability to lower prices, higher quality, and faster delivery (Li et al. 2006). In the same study, Li et al. (2006) also revealed that the impact of supply chain management practices has a positive effect on improving firm performance.

H1: Supply chain management practices has a positive effect on competitive advantage.

$\mathrm{H} 2$ : Supply chain management practices has a positive effect on firm performance.

The development of ICT certainly provides new opportunities for SMEs in overcoming problems. The use of ICTs has been shown to have a positive effect on competitive advantage and supply chain management in companies, as shown in the study by Tripathy et al. (2016). This is supported by the research of Apulu and Latham (2011) and Kushwaha (2011) which state that the adoption of ICT will provide the ability for SMEs to improve services and competitive advantages.

H3: Information and communication technology has a positive effect on supply chain management practices.

H4: Information and communication technology has a positive effect on competitive advantage.

The competitive advantage of a firm illustrates that the firm has advantages over other competitors. The higher the competitive advantage of a firm, it will directly affect the firm's performance (Chaghooshi et al. 2015). A firm will offer high quality products and be offered at a high price, while simultaneously increasing the firm's profit margin and return on investment ( $\mathrm{Li}$ et al. 2006).

H5: Competitive advantage has a positive effect on firm performance

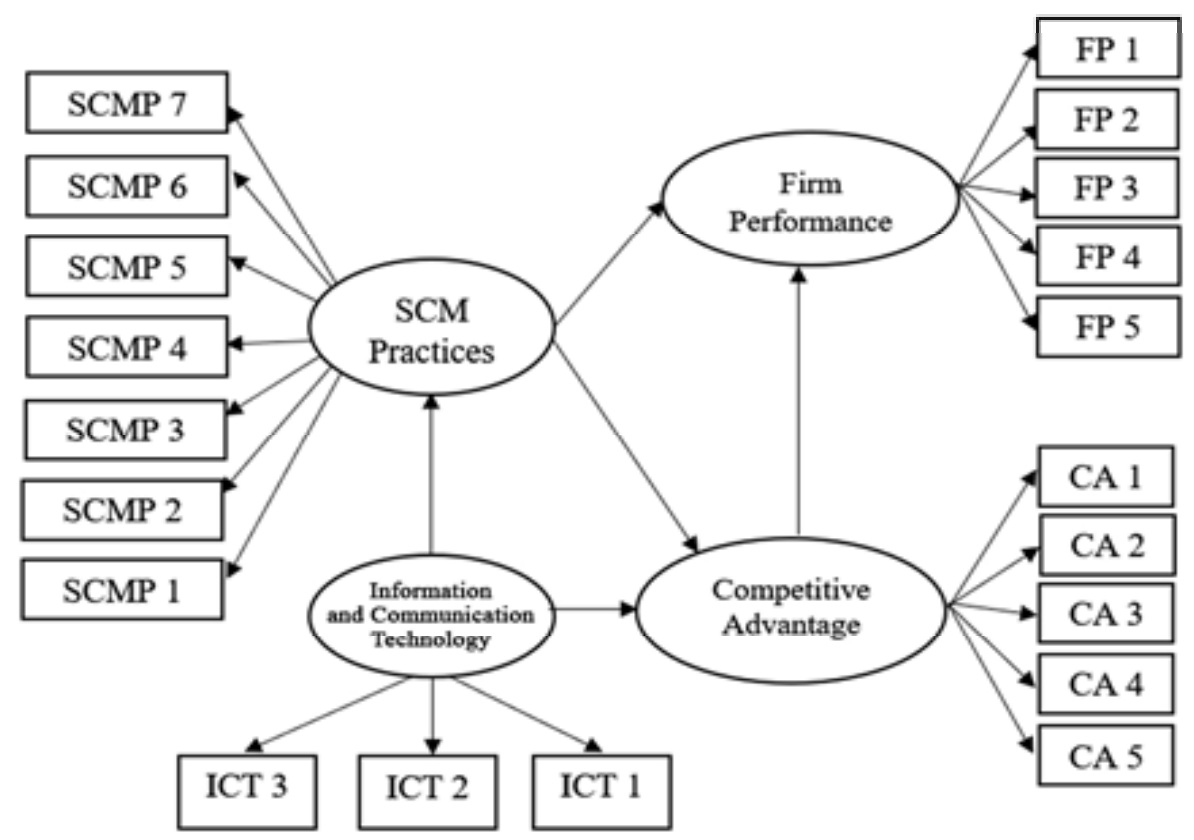

Information: SCMP 1 (Stategic supplier partnership), SCMP 2 (Cutomer relationship), SCMP 3 (Information sharing), SCMP 4 (Information quality), SCMP 5 (Posponement), SCMP 6 (Warehousing management), SCMP 7 (Forecasting), ICT 1 (Information), ICT 2 (Transaction), ICT 3 (Interaction and customization), CA 1 (Price), CA 2 (Quality of product), CA 3 (Delivery), CA 4 (Product innovation), CA 5 (Time to market), FP 1 (Market share), FP 2 (Return on investment), FP 3 (Sales growth), FP 4 (Profit margin on sales), FP 5 (Overall competitive position).

Figure 2. Reseacrh model framework 


\section{RESULTS}

Respondents used in this study were business owners, directors, or business managers engaged in processed food SMEs in DKI Jakarta Province. Of the 927 questionnaires distributed, 249 SMEs filled out the questionnaire. Among them, 244 questionnaires met the criteria for analysis, and five questionnaires did not meet the criteria. The following Table 1 describes adoption of ICT in SMEs, and Table 2 is a descriptive intensity of using ICT infrastructure.

\section{Analysis of Structural Equation Modeling (SEM- AMOS)}

The first stage in conducting this analysis was first order Confirmatory Factor Analysis (CFA). It is a factor analysis method used to empirically test or confirm a measurement model construct. Figure 3 is the initial estimation result of standardized loading factors.

In goodness of fit test of initial model of the research the values of Chi-Square, CMIN/ DF, probability, GFI, AGFI, CFI, TLI, and RMSEA seemed to have a bad indication. Hence, it needed to modify the research model. Several indicators that had a weak loading factor or less than 0.5 were SCMP 5, SCMP 6, SCMP 7 and CA 1. If there is a loading factor value that is smaller than the critical value, the related indicator can be removed from the model. According Hair (2014), factor loadings \pm 0.3 to 0.4 are minimally acceptable. The observed indicators that must be eliminated (removed) included SCMP 5, SCMP 6 and CA 1 as in Figure 4.

Table 1. Adoption ICT of SMEs

\begin{tabular}{|c|c|c|}
\hline What ICT tools do you use? & $\mathrm{n}$ & $\%$ \\
\hline Computer & 100 & 41 \\
\hline Smartphone & 225 & 92,2 \\
\hline Tablet & 35 & 14,3 \\
\hline Software/Application that support the performance & $\mathrm{n}$ & $\%$ \\
\hline System Application and Product in Data Processing (SAP) & 26 & 10,6 \\
\hline Human resource management application & 30 & 12,3 \\
\hline Application of point of sale/cashier & 43 & 17,6 \\
\hline Accounting applications (finance) & 40 & 16,4 \\
\hline $\begin{array}{l}\text { Supply chain management applications (Visual Basic 6, Microsoft Dynamicsuite, Microsoft excel } \\
\text { Macro, SaaS, Bizzy POS, Truckway, Izzy Field Force, Smart Warehouse and others) }\end{array}$ & 26 & 10,6 \\
\hline Tax application & 15 & 6,1 \\
\hline Payment application (SMS Banking, Mobile Banking, Internet Banking) & 118 & 48,3 \\
\hline Delivery application (TIKI, JNE, POS, ojek online, dan lainnya) & 146 & 59,8 \\
\hline Microsoft office & 86 & 35,2 \\
\hline Sales/marketing & $\mathrm{n}$ & $\%$ \\
\hline Market place (Tokopedia, Lazada, Bukalapak, and others) & 116 & 47,5 \\
\hline Website & 36 & 14,7 \\
\hline Facebook & 143 & 58,6 \\
\hline Instagram & 146 & 59,8 \\
\hline Whatsapp & 218 & 89,3 \\
\hline Twitter & 17 & 6,9 \\
\hline Email & 49 & 20 \\
\hline Youtube & 21 & 8,6 \\
\hline
\end{tabular}


Table 2. Descriptive intensity of using ICT infrastructure

\begin{tabular}{|c|c|c|}
\hline Duration of using ICT & $\mathrm{n}$ & $\%$ \\
\hline$<1$ year & 62 & 25,4 \\
\hline$>1-3$ years & 88 & 36 \\
\hline$>3-5$ years & 39 & 16 \\
\hline$>5$ years & 55 & 22,5 \\
\hline Percentage of employees using ICT & $\mathrm{n}$ & $\%$ \\
\hline$<25 \%$ & 88 & 36 \\
\hline$>25 \%-50 \%$ & 42 & 17,2 \\
\hline$>50 \%-75 \%$ & 40 & 16,4 \\
\hline$>75 \%-100 \%$ & 74 & 30,3 \\
\hline Percentage of products sold online & $\mathrm{n}$ & $\%$ \\
\hline$<25 \%$ & 74 & 30,3 \\
\hline$>25 \%-50 \%$ & 41 & 16,8 \\
\hline$>50 \%-75 \%$ & 66 & 27 \\
\hline$>75 \%-100 \%$ & 63 & 25,8 \\
\hline Percentage of products purchased online & $\mathrm{n}$ & $\%$ \\
\hline$<25 \%$ & 124 & 50,8 \\
\hline$>25 \%-50 \%$ & 75 & 30,7 \\
\hline$>50 \%-75 \%$ & 32 & 13,1 \\
\hline$>75 \%-100 \%$ & 13 & 5,3 \\
\hline Internet usage time every day & $\mathrm{n}$ & $\%$ \\
\hline$<8 \mathrm{jam}$ & 133 & 54,5 \\
\hline$>8-16$ jam & 81 & 33,2 \\
\hline$>16-24$ jam & 30 & 12,3 \\
\hline
\end{tabular}

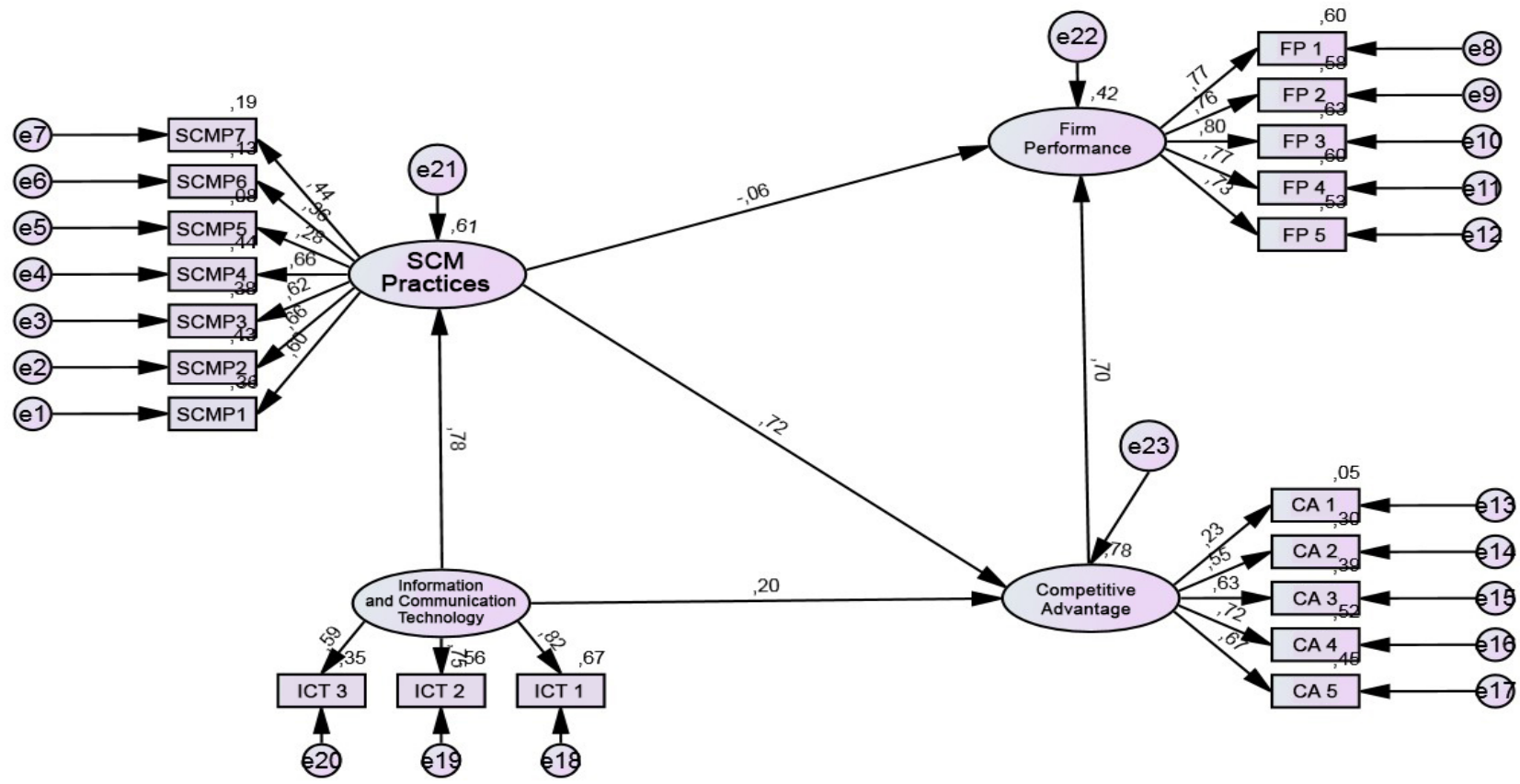

Figure 3. Initial estimation result of standardized loading factors 


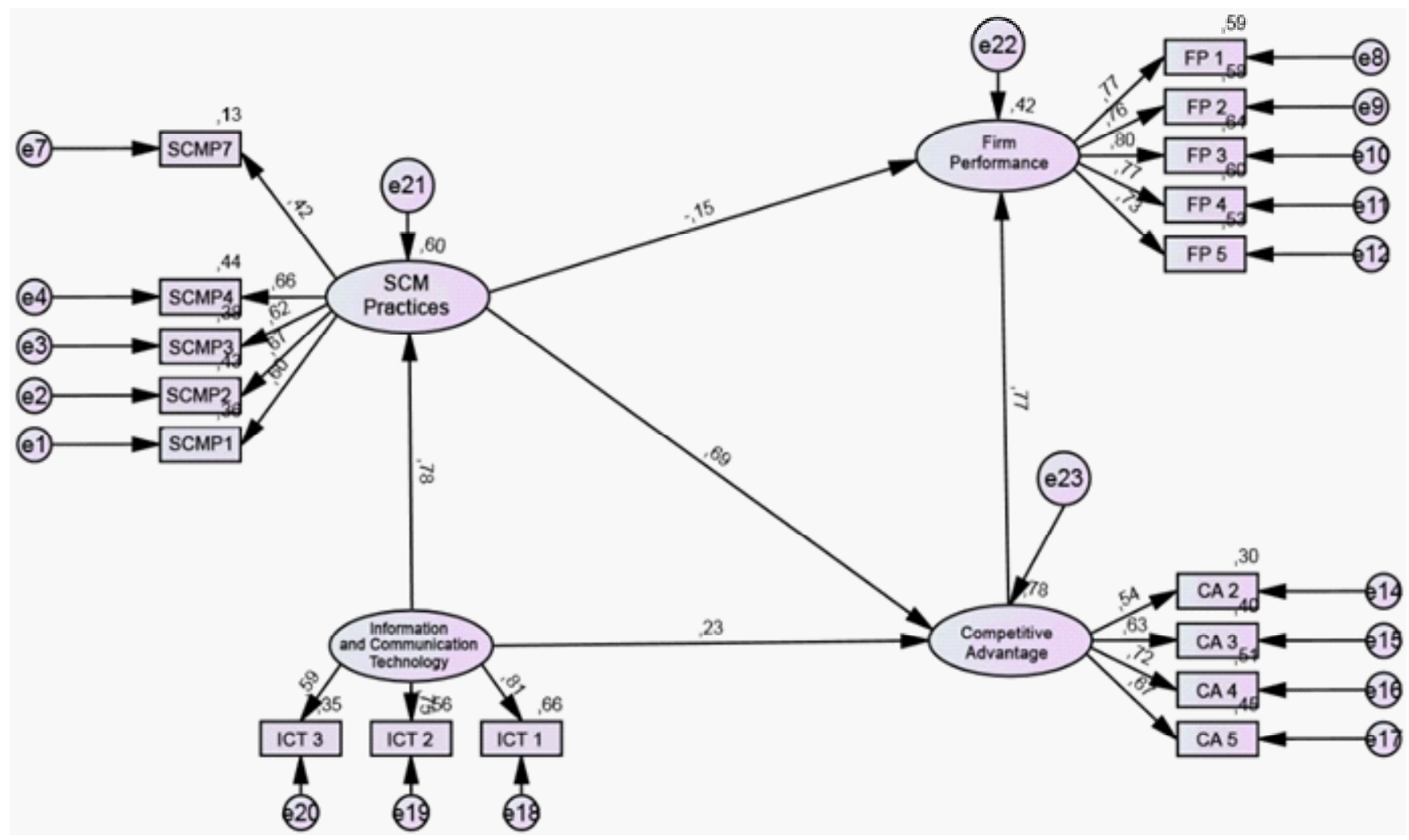

Figure 4. Model after being conducted elimination

Result of goodness of fit from research model after modification in Table 3 showed that the values of ChiSquare, CMIN / DF, GFI, AGFI, CFI, TLI, and RMSEA were still very poor because the goodness of fit was still indicated as poor, then the modification could be continued by looking at the results of the Modification Indices output. Several indicators were eliminated again, including SCMP 2, CA 3, and FP 2. Meanwhile, the indicators that could be conducted by covariances are e 3 to e4; e16 with e18 and e18 with e19 in Figure 5. This was carried out because some of these indicators had a very high Modification Indices value compared to other indicators.

After eliminating and covariances the model, the goodness of fit was much better than before. The results of the analysis on GFI, AGFI, CFI, TLI, CMIN/ DF and RMSEA had met the recommended values. The following Table 4 was the result of goodness of fit testing on the full SEM model.

\section{Hypothesis Test}

Hypothesis test is used to find out whether there is an effect of exogenous variables on endogenous variables. In the Regression Weights, it can be seen that the effect of SCMP on CA, ICT on SCMP, ICT on CA, and CA on FP were significant. This is known because there was a C.R value $\geq 1.96$ or a $P$ value $\leq 0.05$ and there was $* * *$ sign. The relationship between constructs in the hypothesis can be seen from the Regression Weight values in Table 5 .

\section{SCM practice affects competitive advantage}

The practice of supply chain management in this research showed a significant effect on companies' competitive advantage. The $\mathrm{CR}$ value or $\mathrm{t}$-value showed a high number of 3.044 or $\geq 1.967$. Meanwhile, the P-value was 0.002 or $\leq 0.05$. Therefore, $\mathrm{H} 1$ was acceptable. It showed that the implementation of supply chain management practices, especially in strategic partnerships with suppliers, the quality of information, delay, and forecasting, would increase competitive advantage in price capability, product innovation, and ability to face the market. It was supported by previous research ( $\mathrm{Li}$ et al. 2006), who stated that supply chain management practices could build a competitive advantage on product quality, product innovation, and the ability to face the market. This research was also supported by Sukati et al. (2011) that revealed that supply chain management practices had a positive effect toward competitive advantage in price competition, product quality, delivery, product innovation, and time to market. 
Table 3. Result of goodness of fit after being conducted elimination

\begin{tabular}{lccc}
\hline Goodness of Fit Index & Cut off Value (Value Limit) & Result & Criteria \\
\hline$\chi^{2}$ - Chi Square & Expected small & 307.363 & \\
Degree of Freedom & $>0$ & 114 & Over Identified \\
GFI & $\geq 0.90$ & 0.867 & Bad fit \\
AGFI & $\geq 0.90$ & 0.822 & Bad fit \\
CFI & $\geq 0.90$ & 0.866 & Bad fit \\
TLI & $\geq 0.90$ & 0.864 & Bad fit \\
RMSEA & $\leq 0.08$ & 0.084 & Bad fit \\
CMIN/DF & $\leq 2.0$ & 2.696 & Bad fit \\
\hline
\end{tabular}

Table 4. Test result of full model structural equation modeling (SEM)

\begin{tabular}{lccc}
\hline Goodness of Fit Index & Cut off Value (Value Limit) & Result & Criteria \\
\hline$\chi^{2}-$ Chi Square & Expected small & 307.363 & \\
Degree of Freedom & $>0$ & 69 & Over Identified \\
GFI & $\geq 0.90$ & 0.949 & Good fit \\
AGFI & $\geq 0.90$ & 0.922 & Good fit \\
CFI & $\geq 0.90$ & 0.980 & Good fit \\
TLI & $\geq 0.90$ & 0.973 & Good fit \\
RMSEA & $\leq 0.08$ & 0.039 & Good fit \\
CMIN/DF & $\leq 2.0$ & 1.373 & Good fit \\
\hline
\end{tabular}

Table 5. Regression Weights

\begin{tabular}{|c|c|c|c|c|c|}
\hline \multicolumn{2}{|c|}{ Hipotesis } & Estimate & C.R & $\mathrm{P}$ & Result \\
\hline $\mathrm{H} 1$ & $\mathrm{SCMP} \rightarrow \mathrm{CA}$ & .578 & 3.044 & .002 & Accepted \\
\hline $\mathrm{H} 2$ & $\mathrm{SCMP} \rightarrow \mathrm{FP}$ & .101 & .319 & .749 & Not Accepted \\
\hline H3 & $\mathrm{ICT} \rightarrow \mathrm{SCMP}$ & .538 & 6.879 & $* * *$ & Accepted \\
\hline $\mathrm{H} 4$ & $\mathrm{ICT} \rightarrow \mathrm{CA}$ & .235 & 2.058 & .040 & Accepted \\
\hline H5 & $\mathrm{CA} \rightarrow \mathrm{FP}$ & 1.003 & 2.878 & .004 & Accepted \\
\hline
\end{tabular}

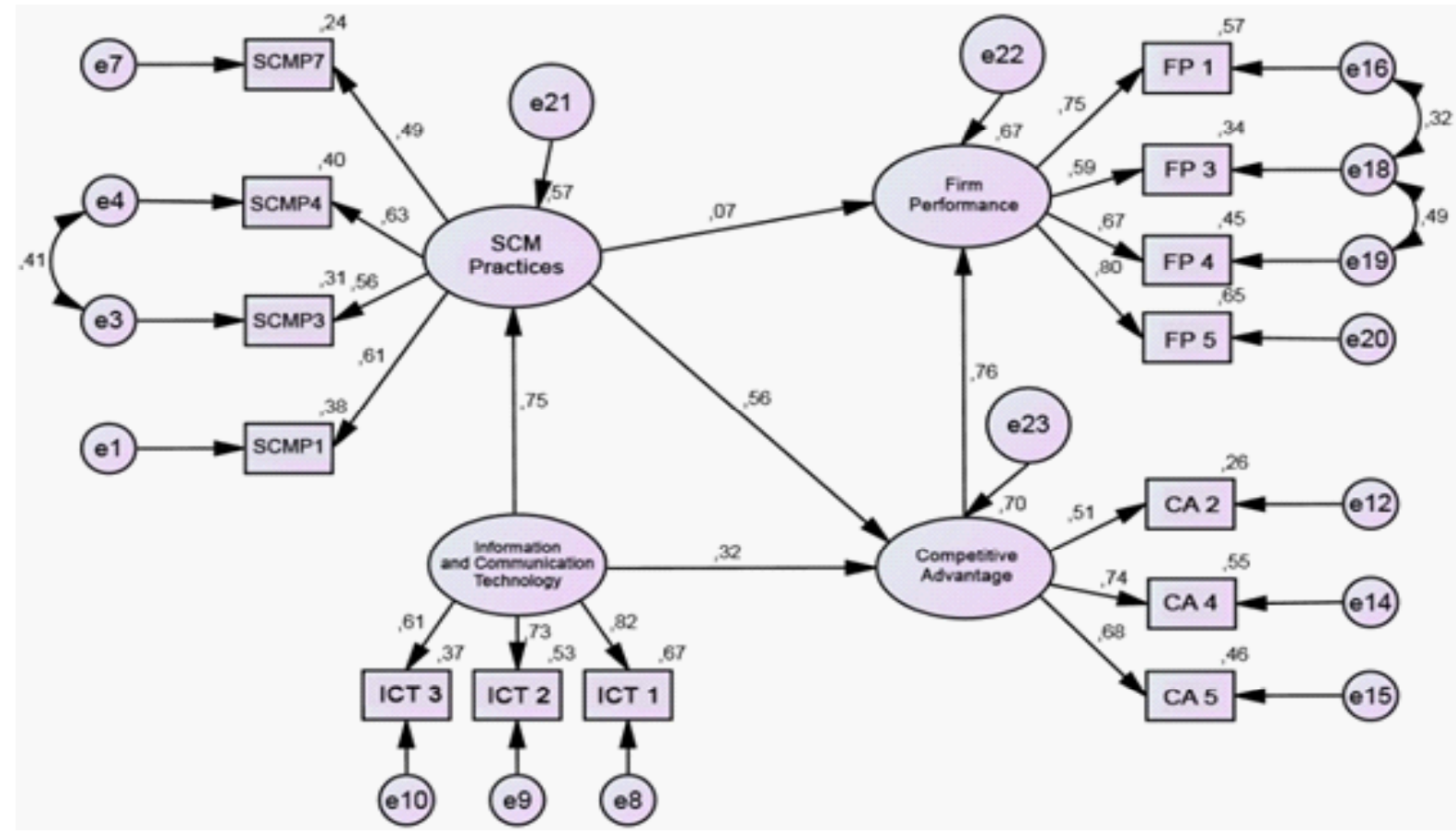

Figure 5. Full model Structural Equation Modeling (SEM) 


\section{ICT affects SCM Practices}

The result of the research showed that information and communication technology affected significantly toward supply chain management practices. The value of C.R or t-value was $6.879 \geq 1.967$ and there was a sign of *** on $\mathrm{P}$ value. Therefore, $\mathrm{H} 3$ could be accepted. The results of this research supported by Tripathy et al. (2016) that argued that the use of ICT was proven to have a positive impact on supply chain management. In this research, ICT had a positive effect on supply chain management practices, especially on cooperative relation with suppliers, sharing information, paying attention to information quality, and forecasting. This research showed that the better the use of ICT in SMEs, the better the supply chain management itself will be.

\section{ICT affects Competitive Advantage}

The result showed that information and communication technology affected significantly toward the competitive advantage of SMEs. The value of C.R or t-value was $2.058 \geq 1.967$. Meanwhile, the $P$ value was 0.04 or $\leq 0.05$. Hence, $\mathrm{H} 4$ was acceptable. The results of this research indicated that the ability of information, transactions, interaction and customization had a positive effect toward competitive advantage in terms of product quality, product innovation, and ability to face the market. The use of ICT was proven to have a positive impact on competitive advantage, as the results in the study of Tripathy et al. (2016). This research was also supported by Kushwaha (2011) who revealed that the adoption of ICT would provide the ability for SMEs to increase their competitive advantage.

\section{Competitive advantage affects firm performance}

The result of he research presented showed that the competitive advantage of SMEs had a significant effect on firm performance. The value of C.R or t-value was $2.878 \geq 1.967$. While the $\mathrm{P}$ value was 0.004 or $\leq 0.05$. Hence, H5 was acceptable. The results of this research indicated that competitive advantages in terms of product quality, product innovation, and ability to face the market can have a positive influence on firm performance, especially on market share that included target market growth and introducing products at the right time. Besides, a competitive advantage strategy was also able to increase sales growth and sales profit margins. Meanwhile, in the overall competitive position, competitive advantage increased the ability to achieve production costs, the ability to offer products according to customer wanted and needed, and the ability to deliver products to customers safely (without defects). The results of this research were supported by Li et al. (2006) that stated that the higher the competitive advantage of a firm, the higher the firm's performance itself.

Based on the observations in Figure 6 and Table 7, it can be seen that the direct effect of supply chain management practices on competitive advantage is 0.565 and the direct effect of supply chain management practices on company performance is 0.075 . Meanwhile, the direct effect of information and communication technology on supply chain management practices has a value of 0.755 . The direct effect of information and communication technology on competitive advantage is 0.322. While the direct effect of competitive advantage on company performance is a value of 0.758 . Then on the observation indirect effect of supply chain management practices on company performance, there is a value of 0.428 . Meanwhile, the indirect effect between information and communication technology on competitive advantage is 0.462 .

\section{Managerial Implications}

Based on analysis result, it is known that competitiveness could be affected by the implementation of supply chain management practices. Therefore, processed food SMEs had to continue to foster cooperative relation with suppliers, share information, pay attention to information quality, and make forecasts. Thus, with the application of supply chain management practices, it would increase competition for product quality, product innovation, and time to market on the competitive advantage of SMEs.

In the application of supply chain management practices, information and communication technology had a significant effect. They consisted of conveying information about products to customers, recording product availability, to find out about competitor developments, facilitate transactions and maintain customer data security, involve customers in the product creation process, and receive input or suggestions that suppliers and customers wanted. Therefore, with the application of information and communication technology, it would improve supply chain management practices in the practice of cooperating relationships with suppliers, sharing information, quality information, 
and forecasting. Meanwhile, in terms of competitive advantage, information and communication technology will increase price competition, product innovation, and time to market.

Meanwhile, firm performance could be affected by application of competitive advantage. By implementing this competitive advantage strategy, it would improve firm performance, especially in market share which includes market growth targets and introducing products at the right time. In addition, the competitive advantage strategy would also increase sales growth and sales profit margins. Whereas in the overall competitive position, competitive advantage could increase the ability to achieve production costs, the ability to offer products according to customer wants and needs, and the ability to deliver products to customers safely (without defects).

\section{CONCLUSIONS AND RECOMMENDATIONS}

\section{Conclusions}

This research can be concluded that supply hain management of SMEs practice has a significant effect toward competitive advantage. Information and communication technology at SMEs has a significant effect toward supply chain management practices. Information and communication technology for SMEs has a significant effect on the competitive advantage of SMEs. The competitive advantage of SMEs has a significant effect on firm performance.

\section{Recommendations}

The further research is expected to use larger number of samples or conduct research in other cities. Thus, SMEs can implement more strategies for the sustainability of their business. Meanwhile, in data collection, you can make negative statements and distribute questionnaires directly. This will avoid biased responses and make it easier for respondents to provide answers.

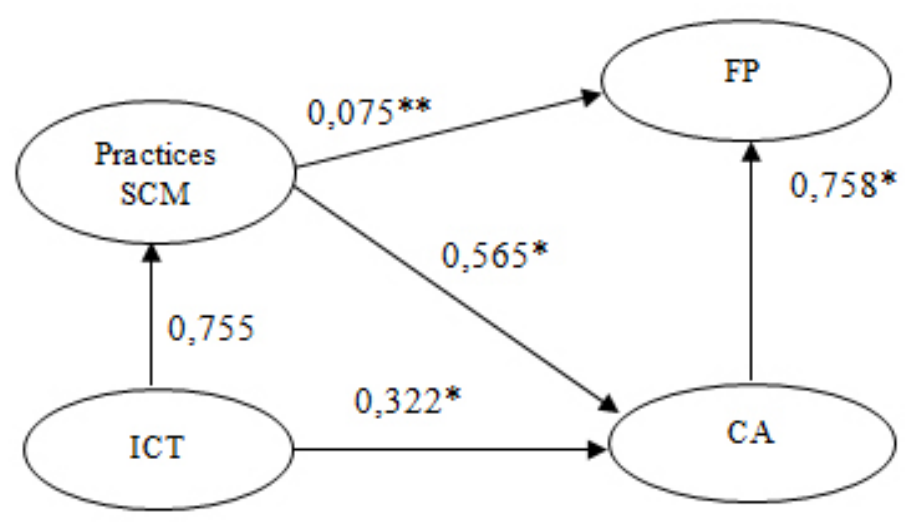

Figure 6. Direct effect (*significant, ${ }^{* *}$ not significant)

Tabel 7. Direct effects, indirect effects and total effects

\begin{tabular}{lccccc}
\hline \multicolumn{7}{c}{ Standardized Direct Effects } & Standardized Indirect Effects & Standardized Total Effects \\
\hline $\mathrm{SCMP}$ & $\rightarrow$ & $\mathrm{CA}$ & .565 & & .565 \\
$\mathrm{SCMP}$ & $\rightarrow$ & FP & .075 & .428 & .503 \\
$\mathrm{ICT}$ & $\rightarrow$ & SCMP & .755 & & .755 \\
$\mathrm{ICT}$ & $\rightarrow$ & CA & .322 & .426 & .748 \\
$\mathrm{CA}$ & $\rightarrow$ & FP & .758 & & .758 \\
\hline
\end{tabular}




\section{REFERENCES}

Abdullah Z, Musa R. 2013. The effect of trust and information sharing on relationship commitment in supply chain management. Procedia Social and Behavioral Sciences 130:266-272. https:// doi.org/10.1016/j.sbspro.2014.04.031.

Apulu I, Latham A. 2011. Drivers for information and communication technology adoption: a case study of nigerian small and medium sized enterprises. International Journal of Business and Management 6(5):51-60. https://doi. org/10.5539/ijbm.v6n5p51.

Chaghooshi AJ, Arbatani TR, Samadi B. 2015. The effect of supply chain management processes on competitive advantage and organizational performance (case study: food industries based in West Azerbaijan Province). Global Journal of Management Studies Researches 2(3):152-157.

Chopra S, Meindl P. 2007. Supply Chain Management: Strategy, Planning and Operation. New Jersey: 5th Edition. Prentice-Hall.

Ghozali I. 2014. Structural Equation Modeling, Metode Alternatif Dengan Partial Least Square (PLS). Semarang: Badan Penerbit Universitas.

Hair JF, Tatham RL, Anderson RE, Black W. 2014. Multivariate Data Analysis. 7th Edition. New Jersey: Pearson Education.

HolwegM.2005.Thethreedimensionsofresponsiveness. International Journal of Operation and Production Management 25(7):603-622. https:// doi.org/10.1108/01443570510605063.

Ibrahim SB, Hamid AA. 2012. Supply chain management practices and supply chain performance effectiveness. International Journal Sciences Research 3(8):187-195.

Katadata. 2017. Barang yang diminati di toko online. https://databoks.katadata.co.id/ datapublish/2017/04/06/barang-apa-palingdiminati-di-toko-online. [6 Apr 2017].

Kasali R. 2017. Disruption. Jakarta: Gramedia Pustaka Utama.

Kurniawan R, Mangunwihardjo S, Perdhana MS. 2019. Analisis pengaruh kemampuan perusahaan, daya respon rantai pasok, dan praktik manajemen rantai pasok terhadap keunggulan bersaing dan kinerja perusahaan (studi pada rantai pasok pelumas Jawa Tengah). Jurnal Bisnis Strategi 27(2):150166. https://doi.org/10.14710/jbs.27.2.150-166.

Kushwaha GS. 2011. Competitive advantage through information and communication technology (ICT) enabled supply chain management practices. International Journal of Enterprise Computing and Business Systems 1(2):3-15.

Li S, Ragu-Nathan B, Ragu-Nathan TS, Subba Rao S. 2006. The impact of supply chain management practices on competitive advantage and organizational performance. The International Journal of Management Science 34(2):107-124. https://doi.org/10.1016/j.omega.2004.08.002.

Prater E, Biehl M, Smith MA. 2001. International supply chain agility-Tradeoffs between flexibelity and uncertainly. International Journal of Operations and Production Management 21(5/6):823-839. https://doi.org/10.1108/01443570110390507.

Schiffman, Kanuk. 2004. Perilaku Konsumen. Jakarta: Prentice Hall.

Sugiyono. 2010. Metode Penelitian Pendidikan Pendekatan Kuantitatif, Kualitatif, dan $R \& D$. Bandung: Alfabeta.

Sukati I, Abdul Hamid AB, Baharun R, Tat HH, Said F. 2011. A study of supply chain management practices:Anempirical investigation on consumer goods industry in Malaysia. International Journal of Business and Social Science 2(17):166-176.

Taneja S, Toombs L. 2014. Putting a face on small business: visibility, viability, and sustainability the impact of social media on small business marketing. Academy of Marketing Studies Journal 18(1):249-260.

Tripathy S, Aich S, Chakraborty A, Lee GM. 2016. Information technology is an enabling factor affecting supply chain performance in Indian SMEs. Journal of Modeling in Management 11(1):269-287. https://doi.org/10.1108/JM2-012014-0004.

Wardhana A. 2015. Strategi digital marketing dan implikasinya pada keunggulan bersaing UKM di Indonesia. Seminar Nasional Keuangan dan Bisnis IV 4:327-335. 